\title{
Reduced Tillage and Intercropping as a Means to Increase Yield and Financial Return in the Drylands of Tigray, northern Ethiopia: A Case Study under Rainfed and Irrigation Conditions
}

\section{Alemtsehay Tsegay ${ }^{1 *}$, Asmeret Kidane², Girmay Tesfay³, Girmay Kahsay ${ }^{3}$, Berhanu Abrha ${ }^{1}$ and Jens B. Aune ${ }^{4}$}

${ }^{1}$ Department of Dryland Crop and Horticultural Science, CDANR, Mekelle University, P. O. Box 231, Mekelle, Ethiopia (*alemtsehay.tsegay@gmail.com).

${ }^{2}$ Maichew Agricultural Technical and Vocational Education and Training College, P.O. Box 67, Maichew, Ethiopia.

${ }^{3}$ Department of Natural Resource Economics and Management, CDANR, Mekelle University, P.O.Box 231, Mekelle, Ethiopia.

${ }^{4}$ Department of International Environment and Development Studies, Noragric, Norwegian University of Life Sciences (NMBU) P.O. Box 5003, N-1432 Ås, Norway.

\begin{abstract}
Intensive tillage is a major sustainability concern in cereal dominated cropping systems in the drylands of Tigray, Ethiopia. Hence, on-farm trials were conducted to investigate the yield and economic advantage of reduced tillage and intercropping for two seasons. A factorial experiment in a complete randomized block design was carried out at Adigudom located in Hintalo-Wajirat district in South-Eastern Tigray in 2014 (rain-fed) and 2015 (irrigated). The experiment consisted of four tillage frequencies (zero, one, two and four) and three types of cropping systems (sole maize, sole soybean and maize-soybean intercropping) in three/four replications. Maize, variety "Melkassa 2", and soybean, variety "Awassa 91" were used. Grain and biomass yields, and harvest index of both crops were analysed. Yield advantage of intercropping was evaluated using land equivalent ratio (LER) and partial budget analysis was used for the financial evaluation. The grain and biomass yields of both crops were significantly increased $(\mathrm{p}<0.05)$ as the tillage frequencies increased from zero to four in both seasons but the frequent tillage with sole cropping was not economically viable as the two times tillage with maize-soybean intercropping gave $126 \%$ greater net benefit compared to the four times tillage sole maize, which is practiced by farmers in the study area. The net benefit was strongly influenced by the main effects of tillage and intercropping in both seasons $(\mathrm{p}<0.001)$ and by their interaction in $2014(\mathrm{p}<0.05)$. Significantly higher LER (1.872.12) was recorded from maize-soybean intercropping over sole cropping in all the tillages and both seasons. Hence, two alternative options are suggested that farmers could apply in the drylands of Tigray: (i) keeping the sole cropping culture of maize production, and reducing number of tillages from 4 to 2 that would give 374\%and 705\% Marginal Rate of Return (MRR), respectively, under the rainfed and irrigated conditions compared to zero tillage sole maize; or (ii) intercropping maize with soybean and reducing tillage frequency from 4to 2 that would give $608 \%$ and $585 \%$ MRR in the respective growing seasons, compared to zero tillage maize-soybean intercropping. Taking these results into account, two times tillage combined with maize-soybean intercropping can be a good option in dryland areas of Tigray to achieve higher total intercrop yield at a low cost and larger LER. Moreover, reduced tillage can minimize soil degradation and benefit farmers with poor access to draft power or female-headed households constrained with labour for ploughing.
\end{abstract}

Keywords: Tillage; Intercropping; Maize; Soybean; Tigray; Ethiopia. 


\section{INTRODUCTION}

Sustainable intensification of agriculture is required to feed the ever-growing population and promote economic growth in developing countries like Ethiopia. In Ethiopia, focus is given on intensive cultivation of cereal crops to achieve food security. Nationally, cereals (mainly maize (Zea mays L.)) cover $79.9 \%$ of the total area and contribute $86.7 \%$ of the total grain production (CSA, 2016). In 2015, maize covered $21.2 \%$ of the total area under cereals in the country while, its grain production is accounted for $30.9 \%$ of total cereal production (CSA, 2016). Maize takes major share of total grain production (average productivity of $2.32 \mathrm{t} \mathrm{ha}^{-1}$ ) although, it is surpassed by tef (Eragrostis tef) in area coverage since 1995 (CSA, 2015). Soybean (Glycine max) is among the legumes like faba bean (Viciafaba), field pea (Pisum sativum), chickpea (Cicer arietinum) and Lentil (Lens culinaris) grown in Ethiopia and ranking $8^{\text {th }}$ in area coverage and production among pulses. In Tigray, the northern Ethiopian highlands, it is newly introduced crop and the largest area coverage recorded was 561.6 ha in 2008/09 (CSA, 2015). However, soybean is the most productive of the grain legume crops with average national yield of $2.13 \mathrm{t} \mathrm{ha}^{-1}(\mathrm{CSA}, 2016)$. The crop is important as it produces more oil and protein per unit of land than almost any other crop, supplies most nutrients and is capable of reducing protein malnutrition (Urgessa Tilahun, 2014). Furthermore, it can be intercropped with maize due to its tolerance to shade and drought, and efficient light utilization (Wright et al., 1988). Despite the significance of soybean in addressing food and nutrition insecurity problems prevailing in the country, generating additional income to the farmers and improving the fertility status of degraded soils, little emphasis is given to its production, specifically in the drylands of Tigray.

Traditional production practices in tropical and subtropical highlands, comprised of intensive tillage, sole cropping and crop residue removal, have resulted in overall degradation of natural resources and subsequent decline in system productivity and sustainability (Govaerts et al., 2009). Agricultural system in northern Ethiopian highlands is characterized by grain production and multiple tillage passages (intensive tillage) to prepare weed-free and flat seedbeds at sowing (Nyssen et al., 2010). Land is cultivated 2-4 times for maize and more for tef before sowing. Unless such kinds of tillage intensity are reduced, soil degradation (soil erosion, poor soil structure, crust formation, poor infiltration, loss of soil organic matter etc.) could be aggravated especially in dryland areas due to cultivation of lands of erosion-prone soils, deforestation and natural calamities (like high rainfall erosivity). Thus, developing field 
management practices with reduced tillage could be an alternative for resource poor farmers including householders without oxen.

A notable success story of conservation agriculture (CA) with zero tillage is reviewed by Bolliger et al. (2006) in Brazil. In this region, sustainable high yield, reduced soil erosion and reduced costs (lower net inputs of fertilizer, fuel and labour) are claimed as the direct benefits of CA. Although, Lal (2007) concluded that the adoption of CA by resource poor small-scale farmers in Sub-Saharan Africa is practically negligible, higher maize yield is observed in western Nigeria. Rockstöm et al. (2009) reported yield improvements of 20 to $120 \%$ from CA trials (with fertilizer) in Ethiopia, Kenya, Tanzania and Zimbabwe. On the other hand, Taa et al. (2004); Borin and Sartori (1995) observed lower yields in wheat and maize, respectively in minimum and zero tillage than conventional tillage. Giller et al. (2009) concluded that yield losses or no yield benefit in CA during short-term periods are likely, although, it can result yield benefits in long-terms.

Intercropping, which is the practice of growing two or more crop species simultaneously in the same land during a growing season is another traditional practice widely used in tropical Africa, subtropical Asia and central South America (Allen and Obura, 1983). Importance of intercropping is described in different literatures: better use of growth resources, less yield variability and overall higher productivity (Willey, 1979); enhance weed suppression, increase disease and pest resistance, and reduce water run-off as a result of rapid development of ground cover (Anil et al., 1998). Generally, intercropping has greater advantages over sole cropping under conditions of moisture and/or nutrient stresses, and works better in the low-input/high-risk environment of most developing regions (Willey et al., 1983), which is typical feature of Adigudom, the study area in Tigray region. Additionally, intercropping would be beneficial for the small-scale farmers enduring shortage of land to grow many crops in a growing season and the hike of costs of inorganic fertilizes.

Despite significant economic and social contribution of intercropping and minimal/no tillage to resource poor farmers, feasibility studies on minimum tillage in combination with maizelegume intercropping have not been undertaken under field conditions in Tigray. Hence, this paper tries to assess the yield and economic advantage of reduced tillage and intercropping compared with the conventional practices (intensive tillage and sole cropping of maize) in Adigudom area in Tigray. 


\section{MATERIALS AND METHODS}

\subsection{Description of the Study Area}

The study was conducted at Adigudom (13 $14^{\prime} \mathrm{N}$ latitude and $39^{\circ} 32^{\prime}$ E longitude) located in Hintalo Wajirat in south-eastern Tigray, having an elevation of $1960 \mathrm{~m}$ above sea level (Fig 1). The rainfall is predominantly unimodal where most of the rain occurs in the period of July to September (main rainy season). Like other parts of Tigray, spatial and temporal variation of rainfall, combined with its erratic nature and poor distribution, and occurrence of dry spells during the main cropping season constrain agricultural production in the area. Adigudom has a mean monthly rainfall and potential reference evapotranspiration of $46 \mathrm{~mm}$ and $117.5 \mathrm{~mm}$ while the mean monthly maximum and minimum temperatures are 24 and $8^{\circ} \mathrm{C}$, respectively, as interpolated by New-Loclim (FAO, 2005).The soil analysis result showed that the soil type of the study area is vertisols with $49 \%$ clay, $29 \%$ sand and $22 \%$ silt. The soil is also classified as neutral ( $\mathrm{pH} 6.9)$ with low content of nitrogen $(0.1 \%)$.

Farming system in Adigudom is a mixed crop-livestock system. Sole cropping, crop rotation and frequent tillage by using oxen are practiced by the farmers. Animal manure is rarely used to improve soil fertility as it is primarily used as source of fuel for cooking. Inorganic fertilizers mainly urea $\left(\mathrm{CO}\left(\mathrm{NH}_{2}\right)_{2}\right)$ and di-ammonium phosphate (DAP) are the most important agricultural inputs to increase crop production in the area. Farmers in Adigudom mostly grow cereal crops like maize, barley (Hordeumvulgare), wheat (Triticumaestivum) and tef. Legumes like field pea and grass pea (Lathyrussativus) are also grown.

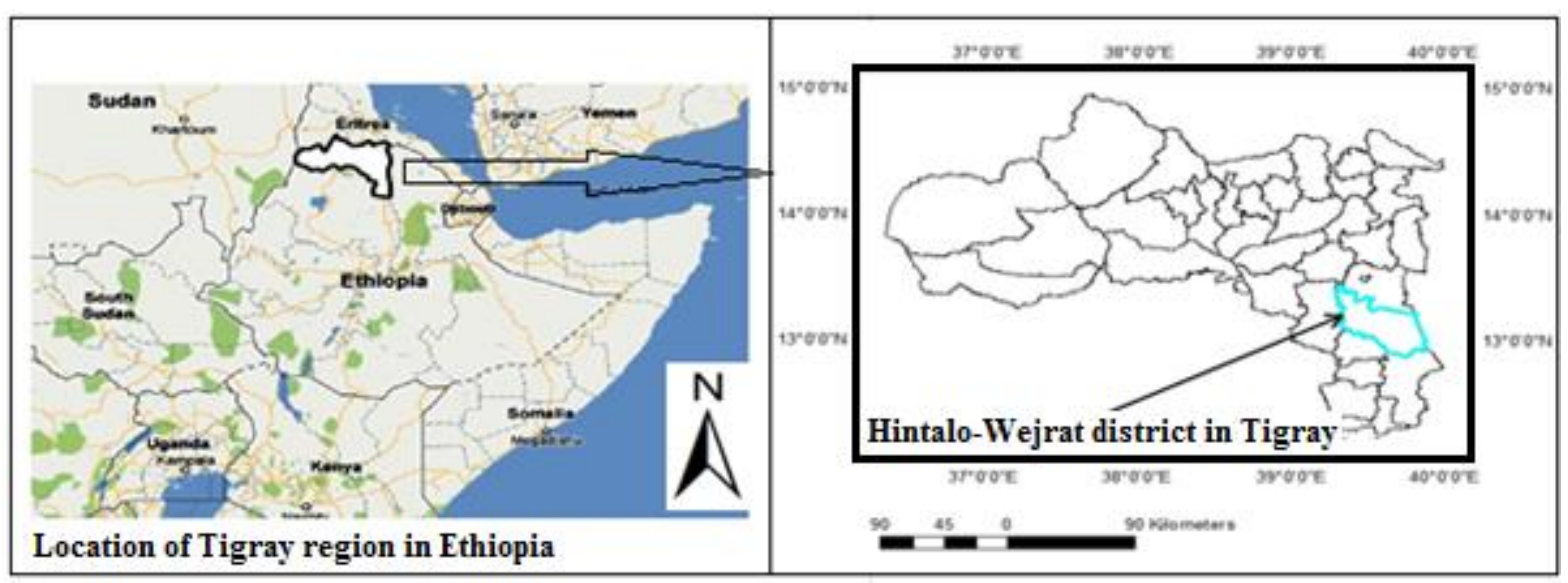

Figure 1. Map of the study area (Modified from Araya and Stroosnijder, 2011).

\subsection{Description of the Field Experiment and Crop Management}

The field experiment was conducted under rain-fed conditions during the main rainy season in2014 and with irrigation in 2015 off season as practiced by the local farmers. During 2014 
the crops were sown on July $7^{\text {th }}$ and in 2015 on $2^{\text {nd }}$ January. A factorial experiment in a complete randomized block design was used consisting of four tillage frequencies (zero, one, two and four) and three types of cropping systems (sole maize, sole soybean and maizesoybean intercropping). The combined treatments were arranged in three fully randomized blocks in 2014 and in four blocks in 2015 with the following description of the tillage frequencies: (i) Zero tillage: the plots were ripped by using pickaxe just to make rows during sowing; (ii) one time tillage: the plots were ploughed once at sowing; (iii) two times tillage: one tillage before sowing and once at sowing; and (iv) four times tillage: three times tillage before sowing and once at sowing. The four times tillage with sole maize treatment is the farmers' practice considered as a control. Tillage was undertaken using an ard-plough called 'Maresha' in Ethiopia.

The maize variety used in the experiment is called "Melkassa 2" and the soybean variety was “Awassa 91". Melkassa 2 is one of the improved varieties released by Melkassa Agricultural Research Centre specifically adapted to the semi-arid agro-ecologies of Ethiopia and is widely used in Tigray region under rain-fed and irrigation condition. Similarly, soybean variety 91 is released in Ethiopia and is under production in research centres in the region. Although, soybean is not commonly grown under field condition by the farmers in the region, it is recommended for intercropping in dryland areas due to its tolerance to drought and shade, and its high productivity. The seeds of maize and soybean were obtained from the official supply sources in the region (Agricultural and Rural Development Bureau and Agricultural Research Center).

Both maize and soybean were sown at the recommended rate of $25 \mathrm{~kg} \mathrm{ha}^{-1}$ and $140 \mathrm{~kg} \mathrm{ha}^{-1}$, respectively. The plot size was $16.8 \mathrm{~m}^{2}$ in 2014 and $12 \mathrm{~m}^{2}$ in 2015. Each plot was separated by $0.5 \mathrm{~m}$ passage and had 6 and 4 rows of maize in the respective years. On the other hand, the number of rows per plot of soybean varied depending upon the cropping systems. It was 8 and 6 rows for sole planting and 5 and 3 rows when intercropped in 2014 and 2015, respectively. The crops were sown simultaneously in rows spaced $0.7 \mathrm{~m}$ for maize and $0.5 \mathrm{~m}$ for soybean. The distance between the plants was $0.25 \mathrm{~m}$ for both crops and $1 \mathrm{~m}$ spacing between blocks. For the intercropped treatments, the crops were sown in alternate rows. All treatments received the recommended rate of nitrogen $\left(64 \mathrm{~kg} \mathrm{ha}^{-1}\right)$ and phosphorous $(46 \mathrm{~kg}$ $\mathrm{P}_{2} \mathrm{O}_{5} \mathrm{ha}^{-1}$ ) in the form of urea and DAP, respectively that corresponds to $100 \mathrm{~kg} \mathrm{ha}^{-1}$ of each. All the DAP and $50 \%$ of the urea were applied at time of sowing and the other $50 \%$ of urea was top dressed at the knee stage of the maize. 
Weeding was carried out by hand as required per the tillage practices. Accordingly, three times hand weeding was performed for zero and onetime tillage, while in two and four tillages, hand weeding was performed twice.

The rainfall during 2014 was sufficient for the growth of the crops although supplementary irrigation (twice) was used during the grain filling stage of maize. In 2015, the crops were fully grown under irrigation as the local farmers' practice by checking the wetness of the soil with finger test and observing the plant condition.

\subsection{Data Collection and Analysis}

Grain yield and dry aboveground biomass were the basic parameters determined at harvest from the central rows of each experimental plot for maize. For soybean, all rows in the intercropping and central rows for sole cropping were used. The collected data were then extrapolated on a hectare bases. Harvest index (HI) was calculated as a ratio of grain yield to dry total above ground biomass. All parameters were subjected to analysis of variance using Genstat $14^{\text {th }}$ edition (as in Payne et al., 2011). Significantly different treatment means were separated using the Duncan's Multiple Range Test at 5\% level of probability.

\subsection{Competition Analysis}

The interaction effect of maize and soybean in a mixture was calculated using a competition index called land equivalent ratio (LER). LER is described as the most appropriate measuring index available for assessing the advantages of intercropping (Willey, 1979) and is an accurate assessment of the greater biological efficiency of intercropping (Khatri et al., 2014). It was computed as described in equation 1. LER greater than one was considered as advantage of intercropping.

$$
\mathrm{LER}_{\text {Total }}=\left(\mathrm{LER}_{\text {maize }}+\mathrm{LER}_{\text {soybean }}\right) \text {---------------------------------------------Equation 1,}
$$

Where, $\mathrm{LER}_{\text {Total }}=$ the sum of LER of maize and soybean; $L E R_{\text {maize }}=\left(\frac{Y_{m s}}{Y_{m}}\right)$;

$L E R_{\text {soybean }}=\left(\frac{Y_{s m}}{Y_{S}}\right) ; Y_{m}$ and $Y_{s}$ are yields of maize and soybean, respectively, as sole crops; $Y_{m s}$ and $Y_{s m}$ are yields of maize and soybean, respectively, as intercrops.

\subsection{Financial Analysis: Comparisons}

Financial analysis was conducted by first constructing the partial budget for each treatment as a basis for dominance and Marginal Rate of Returns (MRR) analyses following the CIMMYT (1988) manual. Total gross benefit was computed based on the average grain yield of both maize and soybean and market price of the grains at the time of harvest. But, in order 
to reflect possible variations incurred between researchers' managed small plots and farmers' managed fields, the average yield was adjusted downward by $10 \%$. Costs that vary in the treatments were the seed cost, fertilizer cost, and the costs of weeding and ploughing (Table 1). The seeds and fertilizer prices were obtained from the official supply sources in the region (Bureau of Agriculture and Rural Development and Agricultural Research Center) at time of planting. The maize and soybean grain price was obtained from the local market price in the study area at harvest (October 2014 for rainfed and May 2015 for irrigation seasons). Labour cost for sowing, harvesting and threshing were considered to be the same for all treatments.All costs and net benefits were computed on Ethiopian Birr (ETB) per hectare basis.

Table 1.Treatment variable costs

\begin{tabular}{|c|c|c|c|}
\hline S.No & Variables & $\operatorname{Cost}(* E T B)$ & Remark \\
\hline \multirow[t]{3}{*}{1.} & $\begin{array}{l}\text { Maize and } \\
\text { soybean seed }\end{array}$ & $11.5 \mathrm{~kg}^{-1}$ for each crop & Sowing periods 2014 and 2015 \\
\hline & Maize grain & 5 and $5.5 \mathrm{~kg}^{-1}$ & $\begin{array}{l}\text { Harvesting periods } 2014 \text { and } 2015, \\
\text { respectively }\end{array}$ \\
\hline & $\begin{array}{l}\text { Soybean } \\
\text { grain }\end{array}$ & 6.7 and $7.0 \mathrm{~kg}^{-1}$ & $\begin{array}{l}\text { Harvesting periods } 2014 \text { and } 2015 \text {, } \\
\text { respectively }\end{array}$ \\
\hline 3. & $\begin{array}{l}\text { Fertilizer } \\
\text { cost }\end{array}$ & $\begin{array}{l}11 \mathrm{~kg}^{-1} \text { Urea, } 15 \mathrm{~kg}^{-1} \\
\text { DAP }\end{array}$ & During sowing period of both seasons \\
\hline \multirow[t]{2}{*}{4.} & \multirow[t]{2}{*}{ Weeding cost } & ${ }^{+} 3360 \mathrm{ha}^{-1}$ & $\begin{array}{l}\text { For two and four times tillage treatments } \\
\text { hand weeded two times each }\end{array}$ \\
\hline & & $+5040 \mathrm{ha}^{-1}$ & $\begin{array}{l}\text { For zero and one time tillage treatments } \\
\text { hand weeded three times each }\end{array}$ \\
\hline \multirow[t]{2}{*}{5.} & \multirow[t]{2}{*}{$\begin{array}{l}\text { Ploughing } \\
\text { cost }\end{array}$} & ${ }^{\dagger} 600 \mathrm{ha}^{-1}$ & $\begin{array}{l}\text { For zero tillage to making rows during } \\
\text { sowing }\end{array}$ \\
\hline & & \multicolumn{2}{|c|}{$\begin{array}{l}\dagger 1200 \mathrm{ha}^{-1} \text { for one time tillage for sole crop and } 2400 \text { when } \\
\text { intercropped; } 2400 \mathrm{ha}^{-1} \text { for two times tillage for sole crop and } \\
3600 \mathrm{ha}^{-1} \text { when intercropped; } 4800 \mathrm{ha}^{-1} \text { for four times tillage for } \\
\text { sole crop and } 6000 \mathrm{ha}^{-1} \text { when intercropped }\end{array}$} \\
\hline
\end{tabular}

Note: *ETB: Ethiopian Birr; ${ }^{+} 60$ ETB person days ${ }^{-1}$ and 28 person days $\mathrm{ha}^{-1}$;

${ }^{\dagger} 60$ ETB person days ${ }^{-1}$ and 10 person days $\mathrm{ha}^{-1}$,

${ }^{\dagger}$ Local rental cost of a pair of oxen including labour in the study area

1 USD $=19.58 \& 20.56$ ETB as per average exchange rate of $2014 \& 2015$, respectively.

Dominance analysis was conducted by listing the treatments according to increasing order of costs that vary and comparing the pattern of net benefits. Those treatments found with decreasing net benefits while the total variable costs increase were eliminated as dominant ones. The non-dominated treatments listed from the lowest cost to the highest cost that vary were subjected to marginal rate of return (MRR) analysis. MRR reveals how net benefit from 
a unit investment increases as the amount invested increases and was computed using equation 2 for the non-dominated treatments.

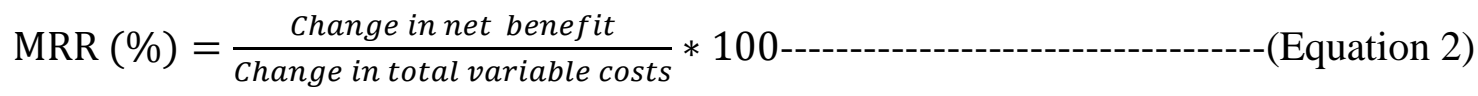

In the marginal analysis, a minimum of $100 \%$ rate of return was assumed acceptable by farmers and any management practice with a return higher than this was considered worthy of investment (CIMMYT, 1988).

To assess the robustness of the financial results, a sensitivity analysis was worked out by increasing the casual base labour cost by $10 \%$ and $15 \%$ as labour was the major cost in the experiment and is negotiable and variable mainly by season and location unlike the seed and fertilizer cost inputs, which have fixed prices at institutional level.

\section{RESULTS}

\subsection{Effect of Tillage on Yield and Yield Components}

The main effects of tillage and intercropping are discussed here as their interaction effect on grain and biomass yields as well as the Harvest Index (HI) of both crops was statistically insignificant in both cropping seasons. Maize grain and biomass yields, and HI were significantly $(\mathrm{p}<0.05)$ affected by tillage frequencies in both cropping seasons (Table 2$)$. Grain and biomass yields increased as the tillage frequency increased from zero to four. In 2014, the biomass yield, respectively, increased by $25 \%$ and $14 \%$ in four times tillage compared with zero and onetime tillage. Similarly, there was a grain yield increment of 5.5\% and $3.7 \%$ in the four times tillage compared with the corresponding tillage. Similar trends were observed in 2015 where, the biomass yield was higher in four times tillage by $20.7 \%$ and $8.8 \%$, and the grain yield by $8.1 \%$ and $5.6 \%$ compared with zero and onetime tillage, respectively. However, the biomass yield difference between two and four times tillage in both seasons, and the grain yield in zero and onetime tillage were statistically insignificant ( $p>0.05$ ) in 2015. The HI ranged between 0.18 and 0.21 was highest in zero tillage in both seasons. Nevertheless, there was no significant difference in HI between two and four times tillage in 2014 and between one, two and four times tillage in 2015 (Table 2).

Soybean grain and biomass yields were highly affected $(\mathrm{p}<0.001)$ by the tillage in both seasons (Table 2). Both parameters increased as the tillage frequency increased. The grain and biomass yields of soybean were improved by $37 \%$ and $49 \%$, respectively in four times tillage in comparison with zero tillage in 2014. In 2015, the grain and biomass yields were more by $51 \%$ and $58 \%$ in the corresponding tillage comparisons. However, the grain yield 
difference between one, two and four times tillage was not significant ( $p>0.05)$ in 2015. This was confirmed by the biomass yield obtained in these three consecutive tillage frequencies (Table 2). But in this case, the highest biomass yield was found in two times tillage with a difference of $4.45 \mathrm{t} \mathrm{ha}^{-1}$ compared with zero tillage. Unlike the maize HI, the soybean HI was not affected by tillage frequencies in both seasons (Table 2).

Table 2. Effect of tillage frequency and intercropping on grain yield (Y), dry aboveground biomass (B) and harvest index (HI) of maize and soybean by season.

\begin{tabular}{|c|c|c|c|c|c|c|c|c|c|c|c|c|}
\hline \multirow{4}{*}{$\begin{array}{l}\begin{array}{l}\text { Main } \\
\text { effects }\end{array} \\
\text { 1. Tillage } \\
\text { frequency }\end{array}$} & \multicolumn{6}{|c|}{ Maize } & \multicolumn{6}{|c|}{ Soybean } \\
\hline & \multicolumn{3}{|c|}{2014 (rainfed) } & \multicolumn{3}{|c|}{2015 (irrigation) } & \multicolumn{3}{|c|}{2014 (rainfed) } & \multicolumn{3}{|c|}{2015 (irrigation) } \\
\hline & $\mathbf{Y}$ & B & \multirow[t]{2}{*}{ HI } & $\mathbf{Y}$ & B & \multirow[t]{2}{*}{ HI } & $\mathbf{Y}$ & B & \multirow[t]{2}{*}{ HI } & $\mathbf{Y}$ & B & \multirow{2}{*}{ HI } \\
\hline & \multicolumn{2}{|c|}{ t ha ${ }^{-1}$} & & \multicolumn{2}{|c|}{ t ha $^{-1}$} & & \multicolumn{2}{|c|}{ t ha $^{-1}$} & & \multicolumn{2}{|c|}{ t ha $^{-1}$} & \\
\hline Zero & 4.20 & 20.11 & 0.21 & 4.33 & 21.22 & 0.20 & 1.69 & 8.92 & 0.19 & 1.24 & 7.31 & 0.18 \\
\hline Onetime & 4.27 & 22.10 & 0.19 & 4.43 & 23.54 & 0.19 & 1.95 & 10.17 & 0.19 & 1.72 & 11.16 & 0.16 \\
\hline Two times & 4.38 & 24.65 & 0.18 & 4.53 & 25.09 & 0.18 & 2.14 & 11.73 & 0.18 & 1.85 & 11.76 & 0.17 \\
\hline Four times & 4.43 & 25.13 & 0.18 & 4.68 & 25.62 & 0.18 & 2.32 & 13.29 & 0.18 & 1.87 & 11.55 & 0.16 \\
\hline LSD $(0.05)$ & 0.136 & 1.172 & 0.01 & 0.219 & 1.152 & 0.013 & 0.174 & 0.671 & 0.022 & 0.216 & 1.642 & 0.04 \\
\hline P-value & 0.009 & $<0.001$ & $<0.001$ & 0.021 & $<0.001$ & 0.004 & $<0.001$ & $<0.001$ & 0.398 & $<0.001$ & $<0.001$ & 0.783 \\
\hline \multicolumn{13}{|c|}{ 2. Intercropping } \\
\hline Sole crop & 4.24 & 23.22 & 0.18 & 4.47 & 23.48 & 0.19 & 2.05 & 11.54 & 0.18 & 1.62 & 8.9 & 0.19 \\
\hline Intercrop & 4.39 & 22.77 & 0.19 & 4.52 & 24.26 & 0.19 & 2.003 & 10.51 & 0.19 & 1.72 & 11.99 & 0.15 \\
\hline $\operatorname{LSD}(0.05)$ & 0.096 & 0.829 & 0.007 & 0.155 & 0.815 & 0.009 & 0.123 & 0.474 & 0.015 & 0.154 & 1.162 & 0.028 \\
\hline $\mathrm{P}$-value & 0.005 & 0.262 & 0.012 & 0.469 & 0.06 & 0.373 & 0.422 & $<0.001$ & 0.16 & 0.178 & $<0.001$ & 0.005 \\
\hline $\mathrm{CV} \%$ & 2.5 & 4.1 & 4.5 & 4.7 & 4.6 & 6.4 & 6.9 & 4.9 & 9.5 & 12.5 & 15.0 & 22.9 \\
\hline
\end{tabular}

Note: $\mathrm{LSD}=$ Least significant difference at $5 \%$ significance level.

Table 3. Land Equivalent Ration of maize and soybean intercropping under various tillage frequencies by season.

\begin{tabular}{|lllllll|}
\hline \multicolumn{7}{c|}{ Land Equivalent Ratio (LER) } \\
\hline & \multicolumn{7}{c|}{$\mathbf{2 0 1 4}$} \\
\hline Tillage frequencies & Zero & One time & Two times & Four times & Mean & LSD (0.05) \\
\hline LER maize & 1.03 & 1.03 & 1.06 & 1.03 & 1.040 & 0.057 \\
\hline LER soybean & 0.84 & 0.97 & 1.06 & 1.03 & 0.980 & 0.210 \\
\hline Total LER & 1.87 & 2.00 & 2.12 & 2.06 & 2.010 & 0.220 \\
\hline & & & $\mathbf{2 0 1 5}$ & & & \\
\hline LER maize & 1.02 & 1.01 & 1.02 & 1.01 & 1.015 & 0.118 \\
\hline LER soybean & 1.06 & 1.08 & 1.06 & 1.11 & 1.078 & 0.291 \\
\hline Total LER & 2.08 & 2.09 & 2.08 & 2.12 & 2.100 & 0.275 \\
\hline
\end{tabular}

\subsection{Effect of Intercropping on Yield and Yield Components}

The response of the component crops to intercropping showed a highly significant $(\mathrm{p}<0.001)$ or significant $(\mathrm{p}<0.05)$ effect on the grain yield and HI of maize in 2014 , soybean biomass yields in both seasons and soybean HI in 2015. The intercropped grain yield and the HI of 
maize were respectively higher by $3.5 \%$ and $5.6 \%$ compared with sole maize in 2014 . On the other hand, intercropping resulted reduction in soybean biomass in 2014 and $\mathrm{HI}$ in 2015by $9.8 \%$ and $26.7 \%$, respectively. However, the biomass yields of soybean in 2015 increased by $34.7 \%$ due to intercropping (Table 2).

Land Equivalent Ratio (LER) was not influenced by tillage frequencies, yet, the total LER was considerably above one in all tillage frequencies in both seasons (Table 3).

\subsection{Financial Analysis}

The net benefit was strongly influenced by the main effects of tillage and intercropping in both seasons $(\mathrm{p}<0.001)$ and by their interaction in $2014(\mathrm{p}<0.05)$. In 2014, the highest net benefits were 19,464.0, 17,918.0, 16,525.0 and 15,089.0ETB ha ${ }^{-1}$ and were obtained, respectively, from two, four, one and zero tillage frequencies combined with maize-soybean intercropping. Similar trend was also observed in 2015. Two times tillage maize-soybean intercropping gave 19,464.0 and 20,505.0 ETB ha ${ }^{-1}$ net benefit, respectively under rain-fed and irrigation compared to the four times tillage sole maize practiced by the farmers in the study area, which gave 8,618.0 and 12,115.0 $\mathrm{ETB} \mathrm{ha}^{-1}$ in the corresponding seasons. The lowest net benefits were obtained from all tillage frequencies with sole soybean in both seasons (Table 4 and 5).

In the dominance analysis (Table 4 and 5), 8 of the 12 treatment combinations were dominated (eliminated) due to less net return at higher cost. The farmers' practice along with the other treatments was dominated. The dominance analysis result was insensitive to labour cost changed between $+10 \%$ to $+15 \%$ in both seasons (Table 4 and 5 ). The non-dominated treatments from Table 4 and 5 were used for MRR analysis (Table 6). Table 6 shows the MRR analysis results. Changing the tillage occurrence from zero to two for sole maize returned 374\% and 705\% MRR in 2014 and 2015, respectively. While, changing the tillage frequency from zero to two for maize-soybean inter cropping gave $608 \%$ and $585 \%$ MRR for the respective years.

On the other hand, moving from two times tillage sole maize to zero tillage intercropped maize returned MRR of $97 \%$ in 2014 and 59\% in 2015, which were below the minimum acceptable rate of return. 
Table 4. Dominance and sensitivity analysis for the treatment combinations in 2014

\begin{tabular}{|c|c|c|c|c|c|c|c|c|}
\hline \multirow[t]{3}{*}{ Treatment combinations } & \multicolumn{3}{|c|}{2014 cropping season } & \multicolumn{5}{|c|}{ Sensitivity analysis } \\
\hline & $T V C$ & Net benefit & \multirow[t]{2}{*}{$\begin{array}{l}* * \text { Dominance } \\
\text { analysis result }\end{array}$} & $\begin{array}{l}\text { TVC }(+10 \% \\
\text { labour cost) }\end{array}$ & $\begin{array}{l}\text { Net } \\
\text { benefit }\end{array}$ & $\begin{array}{l}\text { TVC }(+15 \% \\
\text { labour cost })\end{array}$ & $\begin{array}{l}\text { Net } \\
\text { benefit }\end{array}$ & \multirow{2}{*}{$\begin{array}{l}* * \text { Dominance } \\
\text { analysis result }\end{array}$} \\
\hline & \multicolumn{2}{|c|}{$*\left(E T B h^{-1}\right)$} & & \multicolumn{2}{|c|}{$\left(E T B h^{-1}\right)$} & \multicolumn{2}{|c|}{$\left(E T B h a^{-1}\right)$} & \\
\hline Zero tillage sole maize & $8,528.0$ & $10,088.0$ & ND & $9,092.0$ & $9,524.0$ & $9,374.0$ & $9,242.0$ & ND \\
\hline Two tillage sole maize & $8,648.0$ & $10,537.0$ & ND & $9,224.0$ & $9,961.0$ & $9,512.0$ & $9,673.0$ & ND \\
\hline One tillage sole maize & $9,128.0$ & $9,773.0$ & $\mathrm{D}$ & $9,752.0$ & $9,149.0$ & $10,064.0$ & $8,837.0$ & $\mathrm{D}$ \\
\hline Zero tillage sole soybean & $9,850.0$ & $1,225.0$ & $\mathrm{D}$ & $10,414.0$ & 661.0 & $10,696.0$ & 379.0 & $\mathrm{D}$ \\
\hline Two tillage sole soybean & $9,970.0$ & $2,592.0$ & $\mathrm{D}$ & $10,546.0$ & $2,016.0$ & $10,834.0$ & $1,728.0$ & $\mathrm{D}$ \\
\hline One tillage sole soybean & $10,450.0$ & $1,530.0$ & $\mathrm{D}$ & $11,074.0$ & 906.0 & $11,386.0$ & 594.0 & $\mathrm{D}$ \\
\hline Four tillage sole maize & $11,048.0$ & $8,618.0$ & $\mathrm{D}$ & $11,864.0$ & $7,802.0$ & $12,272.0$ & $7,394.0$ & $\mathrm{D}$ \\
\hline Four tillage sole soybean & $12,370.0$ & $1,479.0$ & $\mathrm{D}$ & $13,186.0$ & 663.0 & $13,594.0$ & 255.0 & $\mathrm{D}$ \\
\hline Zero tillage intercropped & $13,338.0$ & $15,089.0$ & ND & $13,962.0$ & $14,465.0$ & $14,274.0$ & $14,153.0$ & ND \\
\hline Two tillage intercropped & $14,058.0$ & $19,464.0$ & ND & $14,754.0$ & $18,768.0$ & $15,102.0$ & $18,420.0$ & ND \\
\hline One tillage intercropped & $14,538.0$ & $16,525.0$ & $\mathrm{D}$ & $15,282.0$ & $15,781.0$ & $15,654.0$ & $15,409.0$ & $\mathrm{D}$ \\
\hline Four tillage intercropped & $16,458.0$ & $17,918.0$ & $\mathrm{D}$ & $17,394.0$ & $16,982.0$ & $17,862.0$ & $16,514.0$ & $\mathrm{D}$ \\
\hline
\end{tabular}

Note: TVC=Total variable cost; *1 USD $=19.17$ and 20.65 ETB as per average exchange rate on December 2014 \& June 2015,respectively, which were the harvesting periods for each season (2014 and 2015);**ND=non-dominated and $\mathrm{D}=$ dominated. 
Table 5. Dominance and sensitivity analysis for the treatment combinations in 2015

\begin{tabular}{|c|c|c|c|c|c|c|c|c|}
\hline \multirow[t]{3}{*}{ Treatment combinations } & \multicolumn{3}{|c|}{2015 cropping season } & \multicolumn{5}{|c|}{ Sensitivity analysis } \\
\hline & $T V C$ & t benefit & $\begin{array}{l}* * \text { Dominance } \\
\text { analysis result }\end{array}$ & $\begin{array}{l}\text { TVC } \\
(+10 \% \\
\text { labour } \\
\text { cost })\end{array}$ & Net benefit & \begin{tabular}{|l|} 
TVC \\
$(+15 \%$ \\
labour \\
cost $)$
\end{tabular} & \begin{tabular}{|l|} 
Net \\
benefit
\end{tabular} & $\begin{array}{l}\text { **Dominance } \\
\text { analysis result }\end{array}$ \\
\hline & \multicolumn{2}{|c|}{$*\left(E T B a^{-1}\right)$} & & \multicolumn{2}{|c|}{$\left(E T B h a^{-1}\right)$} & \multicolumn{2}{|c|}{$\left(E T B a^{-1}\right)$} & \\
\hline Zero tillage sole maize & $8,528.0$ & $12,680.0$ & ND & $9,092.0$ & $12,116.0$ & $9,374.0$ & $11,834.0$ & ND \\
\hline Two tillage sole maize & $8,648.0$ & $13,526.0$ & ND & $9,224.0$ & $12,950.0$ & $9,512.0$ & $12,662.0$ & ND \\
\hline One tillage sole maize & $9,128.0$ & $12,756.0$ & $\mathrm{D}$ & $9,752.0$ & $12,132.0$ & $10,064.0$ & $11,820.0$ & $\mathrm{D}$ \\
\hline Zero tillage sole soybean & $9,850.0$ & $-2,209.0$ & $\mathrm{D}$ & $10,414.0$ & $-2,773.0$ & $10,696.0$ & $-3,055.0$ & $\mathrm{D}$ \\
\hline Two tillage sole soybean & $9,970.0$ & $1,504.0$ & $\mathrm{D}$ & $10,546.0$ & 928.0 & $10,834.0$ & 640.0 & $\mathrm{D}$ \\
\hline One tillage sole soybean & $10,450.0$ & 100.0 & $\mathrm{D}$ & $11,074.0$ & -524.0 & $11,386.0$ & -836.0 & $\mathrm{D}$ \\
\hline Four tillage sole maize & $11,048.0$ & $12,115.0$ & $\mathrm{D}$ & $11,864.0$ & $11,299.0$ & $12,272.0$ & $10,891.0$ & $\mathrm{D}$ \\
\hline Four tillage sole soybean & $12,370.0$ & $-1,247.0$ & $\mathrm{D}$ & $13,186.0$ & $-2,063.0$ & $13,594.0$ & $-2,471.0$ & $\mathrm{D}$ \\
\hline Zero tillage intercropped & $13,338.0$ & $16,296.0$ & ND & $13,962.0$ & $15,672.0$ & $14,274.0$ & $15,360.0$ & ND \\
\hline Two tillage intercropped & $14,058.0$ & $20,505.0$ & ND & $14,754.0$ & $19,809.0$ & $15,102.0$ & $19,461.0$ & ND \\
\hline One tillage intercropped & $14,538.0$ & $18,592.0$ & $\mathrm{D}$ & $15,282.0$ & $17,848.0$ & $15,654.0$ & $17,476.0$ & $\mathrm{D}$ \\
\hline Four tillage intercropped & $16,458.0$ & $19,103.0$ & $\mathrm{D}$ & $17,394.0$ & $18,167.0$ & $17,862.0$ & $17,699.0$ & $\mathrm{D}$ \\
\hline
\end{tabular}

Note: TVC=Total variable cost; *1 USD $=19.17$ and 20.65 ETB as per average exchange rate on December 2014 \& June 2015 , respectively, which were the harvesting periods for each season (2014 and 2015);**ND=non-dominated and $\mathrm{D}=$ dominated. 
Table 6. Marginal Rate of Return analysis for non-dominated treatments by season

\begin{tabular}{|llll|}
\hline Growing season & $\mathbf{2 0 1 4}$ & & \\
\hline & $\begin{array}{l}\text { Incremental } \\
\text { Cost } \\
(\boldsymbol{E T B})\end{array}$ & $\begin{array}{l}\text { Incremental } \\
\text { Benefit } \\
(\boldsymbol{E T B})\end{array}$ & $\begin{array}{l}\text { Marginal Rate of } \\
\text { Return (\%) }\end{array}$ \\
\hline Zreatments & - & - & - \\
\hline Two tillage sole maize & 120 & 449 & 374 \\
\hline Zero tillage intercropped & 4690 & 4552 & 97 \\
\hline Two times tillage intercropped & 720 & 4375 & 608 \\
\hline Growing season & $\mathbf{2 0 1 5}$ & & \\
\hline Zero tillage sole maize & - & - & - \\
\hline Two times tillage sole maize & 120 & 846 & 705 \\
\hline Zero tillage intercropped & 4690 & 2770 & 59 \\
\hline Two times tillage intercropped & 720 & 4209 & 585 \\
\hline
\end{tabular}

Note: ETB is Ethiopian Birr.

\section{DISCUSSION}

\subsection{Effect of Tillage on Yield and Yield Components}

Our findings revealed significant effect $(\mathrm{p}<0.05)$ of tillage frequency on grain and biomass yields of both crops in both cropping seasons. Greater grain and biomass yields of maize and soybean were found in four times tillage compared with the fewer tillage frequencies. The similar results obtained in biomass yields of both crops in two and four times tillage (except in soybean biomass in 2014) may be a good indicator not to plough land prepared for maize more than twice, as the additive effect on the grain and biomass yields was insignificant. One of the possible reasons for low grain and biomass yields in the zero and onetime tillage could be associated with the stunted growth of the crops (as observed), which might be related to poor root development due to increasingly higher soil strength at deeper layers, unlike the conventional tillage that provide good depth of loose soil that facilitate uptake of water and nutrients. Our results are consistent with Rusinamhodzi et al. (2011) who found a lower maize grain yield in reduced tillage in semi-arid areas, Sornpoon and Jayesuria (2013) who remarked intensive tillage as an effective method for increasing maize production and improving soil physical properties, and Getachew Sime et al. (2015) who reported an increased grain and stover yield of maize in four times tillage compared to the minimum tillages (zero and one) in the central rift valley of Ethiopia. Similarly, Taa et al. (2004); and Borin and Sartori (1995) observed lower yields in wheat and maize, respectively in minimum and zero tillage than conventional tillage. However, the review work of Worku Burayu et al. (2001) found maize grain yields lower on conventional tillage compared to conservation tillage in Ethiopia. From our results and others' findings, it can be suggested that although (C) CNCS, Mekelle University 
conservation tillage (no tillage) is proposed for many advantages: increase stored soil water by conserving the soils' natural structure and by reducing soil evaporation; increase soil fertility by minimizing soil erosion and increasing soil organic matter, its effect on yield is rather a long term (increase over time) that contrasts with the farmers' intension. Thus, extensive on-farm experimentation in participatory approach is required to adopt the technology by the farmers.

HarvestIndex (HI) that describes the efficiency of a crop to partition part of the biomass produced into economical yield was negatively affected as the tillage frequency in maize increased in both seasons.It was greater in zero tillage than the other tillage treatments. This could be related with the longer time it takes to mature maize in zero tillage (data not shown), which allow for better grain filling. On the other hand, Khatri et al. (2014) reported no effect of tillage frequency and intercropping systems on the HI of maize.

\subsection{Effect of Intercropping on Yield and Yield Components}

The effect of intercropping was significant on grain yield of maize in 2014 and soybean biomass yields in both seasons (Table 2). However, one of the most important advantages of intercropping system is to increase productivity per unit area, which is measured using the Land Equivalent Ratio (LER). Regardless of the tillage frequencies, the total LER was greater than one in both cropping seasons (Table 3), revealing the productivity advantage of intercropping over sole cropping. The total LER ranges from 1.87-2.08 in zero tillage, 2.0 2.09 in onetime tillage, 2.08-2.12 in two times tillage and 2.06-2.12 in four times tillage (Table 3). This implies that to equal the yield of maize-soybean intercrop, about $87-108 \%$, $100-109 \%, 108-112 \%$ and 106-112\% more land would be required in sole cropping of either of the crops in the corresponding tillage frequencies.

Similar results were reported for mixed cropping systems of maize and soybean (Khatri et al., 2014) and maize and common bean/cowpea (Yilmaz et al., 2008). The possible reasons for grain yield advantage of intercropping over sole cropping as per many literatures disclosed could be due to: (i) greater water use efficiency as better root distribution in the root zone and reduced runoff due to increased soil cover; (ii) more water transpiration through crops instead of water lost through evaporation from the soil; (iii) better light absorption and utilization; and (iv) less competition for nitrogen because of soybean's ability to fix nitrogen. Willey (1990) reported an increased proportion of transpiration due to intercropping in drier conditions due to decreased soil temperature and thereby increased growth without increasing 
total water demand. The author also reported efficient light utilization was more achievable than light absorption in intercropping of millet-groundnut.

Another reason for the claim on the advantage of intercropping is its ability to avoid risk, i.e., if one crop fails or grows poorly, the other component (or complement) crop can compensate (Willey,1979). Besides, intercropping can reduce incidence of pests and diseases either by reducing their spread, as one component crop can serve as a trap-crop or a repellent to detour the pest of the other crop, or enhance the abundance of predators (Lithourgidis et al., 2011). Weed control is an additional important aspect of intercropping if the intercrops are more effective than sole crops in suppressing weeds (Lithourgidis et al., 2011).Thus, with all the aforementioned evidences, intercropping of cereals with legumes could be a good opportunity for poor resource farmers in Tigray where, crop failures are common due to various factors like drought, pests and/or diseases attack, weeding, which is the most tedious and time consuming activity and chemical herbicides or insecticides that are either expensive or unavailable.

\subsection{Financial Analysis}

Higher net benefit of 19,464.0 ETB ha ${ }^{-1}$ was recorded from two tillage maize-soybean intercropping compared to the farmers' practice, which gave 8,618.0 $\mathrm{ETB} \mathrm{ha}^{-1}$ under rainfed condition. This is a $126 \%$ increment, which is due to the high total yield of maize and soybean intercropping and less cost for tillage. MRR analysis was conducted to evaluate the economic viability of both tillage and intercropping systems. From the 12 treatment combinations, those selected for MRR analyses due to their high net returns at low cost were: (i) two times tillage intercropped, (ii) zero tillage intercropped, (iii) two times tillage sole maize and (v) zero tillage sole maize (see Table $4 \& 5$ ). The MRR was $374 \%$ and $705 \%$ when moving from zero tillage sole maize to two times tillage sole maize in 2014 and 2015, respectively (Table 6). Similarly, two times tillage maize-soybean intercropping gave $608 \%$ and 585\% MRR than the zero tillage maize-soybean intercropping in the respective years. This implies that the two times tillage maize-soybean intercropping was more stable than two times tillage sole maize. In such a system, a farmer can have an extra gain of 5.85 to 6.08ETB while recovering the initial investment of 1 ETB in the system. Comparable results were reported by Khatri et al. (2014). The insensitiveness of the dominance analysis to changing labour cost between $+10 \%$ to $+15 \%$ also indicated that the introduced practice is robust and valuable to recommend in the study area and areas with similar environmental conditions. 
Finally, it is concluded that two times tillage maize-soybean intercropping as a promising alternative package for farmers in dryland areas of Tigray. This system has greater total intercrop yield, higher LER, higher net benefit and MRR at low cost and may benefit farmers with poor access to draft power and/or female-headed households constrained with labour for ploughing.

\section{CONCLUSION}

The result of this study demonstrated that reducing tillage intensity by half (from four to two) for maize production would benefit the farmers in Tigray for various reasons: (i) as evidenced by the MRR analysis, it is economically profitable; (ii) it might reduce soil disturbance due to intensive tillage that deteriorate the soil structure; (iii) it might make the soil loose for enhancement of root proliferation; (iv) it incorporates crop residues (if any) with soil; and (v) it prevents early emerging weeds. Nevertheless, developing an integrated package is crucial, as a single approach may not address the complex issue of crop production in dryland areas. It was for this reason we combined the different tillage frequencies with sole maize, sole soybean and intercropped maize-soybean cropping systems to evaluate their synergy. The results showed that although the highest grain and biomass yields of both crops were obtained in the highest tillage frequency (four times tillage, which is the farmers' practice), it was not economically viable. Similarly, the normally practiced maize sole cropping system was not efficient in resource utilization, and intercropping was identified as a promising practice. Thus, reducing tillage frequency from four to two combined with maize-soybean intercropping would be a good alternative for the resource poor farmers in dryland areas like Tigray. Such a system gives a greater total intercrop yield at a low cost, higher land equivalent ratio that indicates a greater productivity per unit area, diversifies production, minimizes soil degradation caused by intensive tillage and may benefit farmers with poor access to draft power or female-headed households constrained with labour for ploughing.

However, extensive on-farm experimentation in participatory approach is required to introduce the integrated farming management of reduced tillage and intercropping as improvement in yield as a result of improved soil fertility (increase organic matter content, soil carbon sequestration, improving soil structure, infiltration, water holding capacity etc.) through those practices is rather a long term effect that contrasts the farmers intention, who mostly use extractive farming for short term gains rather than investing in long term practice. Furthermore, as intercropping of cereals with legumes is not commonly practiced in the 
drylands of Tigray, conducting a series of maize-legume intercropping trials is recommended to find correct match of companion legume species with maize. Besides, further study on the impact of intercropping on suppressing weeds that compromise the weeding problem in zero or minimum tillage is important.

\section{ACKNOWLEDGEMENTS}

This research is supported by the NORHED through the Research and Capacity Building for Climate Smart Agriculture Development in the Horn of Africa project. We are grateful to the Hintalo-Wajirat district Bureau of Agriculture and Rural Development and the development agents working in Adigudom site for their unreserved support during the study period. We also thank farmer Abadi Tsegay and his family for their support during field trials.

\section{REFERENCE}

Allen, J. R \& Obura, R. K. 1983. Yield of corn and soybean under different intercropping systems. Agronomy Journal, 75(6): 1005-1009.

Anil, L., Park, J., Phipps, R. H \& Miller, F. A. 1998. Temperate intercropping of cereals for forage: a review of the potential for growth and utilization with particular reference to the UK. Grass and Forage Science, 53: 301-317.

Bolliger, A., Magid, J., Amado, T. J. C., Neto, F. S., Ribeiro, M. F. S., Calegari, A.,Ralisch, R \& Neergaard, A. 2006. Taking Stock of the Brazilian "Zero- Till Revolution". A review of Landmark Research and Farmers' practice. Adv. in Agronomy, 91: 47-64.

Borin, M \& Sartori, L. 1995.Barley, soybean and maize production using ridge tillage, notillage and conservational tillage in north-east Italy. Journal of Agricultural Engineering Research, 62: 229-236.

Central Statistical Agency of Federal Democratic Republic of Ethiopia (CSA). 2015. Time Series Data for National \& Regional level from 1995/96-2014/15. In: Report on area and production of crops (meher season). Addis Ababa, Ethiopia.

Central Statistical Agencyof Federal Democratic Republic of Ethiopia (CSA) \& Living Standards Measurement Study (LSMS).2015. Ethiopia Socioeconomic Survey Report 2013/14.Central Statistical Agency and World Bank. Addis Ababa, Ethiopia.

Central Statistical Agency of Federal Democratic Republic of Ethiopia (CSA). 2016. Agricultural sample survey (2015/16). Volume I. In: Report on Area and Production of Major Crops (meher season). Statistical Bulletin No. 584. Addis Ababa, Ethiopia. 
CIMMYT (The International Maize and Wheat Improvement Centre). 1988. From Agronomic Data to Farmer Recommendations: An Economics Training Manual. Mexico, D.F.

Food and Agriculture Organization of the United Nations (FAO). 2005. New LocClim: Local Climate Estimator. Environment and Natural Resources. In: Working Paper No. 20. (CD-ROM). FAO, Rome.

Getachew Sime, Aune, J. B \& Mohammed, H. 2015. Agronomic and economic response of tillage and water conservation management in maize, Central rift valley in Ethiopia.Soil and Tillage Research, 145: 20-30.

Giller, K. E., Witter, E., Corbeels, M \& Tittonell, P. 2009. Conservation agriculture and smallholder farming in Africa: The heretics' view. Field Crops Research, 114: 23-34.

Govaerts, B., Sayre, K. D., Goudeseune, B., De Corte, P., Lichter, K., Dendooven, L\& Deckers, J. 2009. Conservation agriculture as a sustainable option for the central Mexican highlands. Soil \& Tillage Research, 103: 222-230.

Khatri, N., Dahal, K. R., Amgain, L. P \& Karki, T. B. 2014. Productivity and Economic Assessment of Maize and Soybean Intercropping under Various Tillage and Residue Levels in Chitwan, Nepal. World Journal of Agricultural Research, 2(6A): 6-12. (Available online at http://pubs.sciepub.com/wjar/2/6A/2)

Lal, R. 2007. Constraints to adopting no-till farming in developing countries. Soil \& Tillage Research, 94: 1-3.

Lithourgidis, A. S., Dordas, C. A., Damamas, C. A \& Vlachostergious, D. N. 2011. Annal intercrops: an alternative pathway for sustainable agriculture. Review article. Australian Journal of crop Science, 5(4): 396-410.

Nyssen, J., Govaerts, B., Araya, T., Cornelis, W., Bauer, H., Haile, M., Sayre, K \& Deckers, J. 2010. Review article: The use of the marasha ard plough for conservation agriculture in Northern Ethiopia. Agronomy for Sustainable Dev., 31: 287-297.

Payne R. W., Harding S. A., Murray, D. A., Soutar, D.M., Baird, D. B., Glaser, A. I., Welham, S. J., Gilmour, A. R., Thompson, R \& Webster, R. 2011. GenStat Release 14 Reference Manual. Part 2 Directives. VSN International, Hemel Hempstead, UK.

Rockström, J., Kaumbutho, P., Mwalley, J., Nzabi, A. W., Temesgen, M., Mawenya, L., Barron, J., Mutua, J \& Damgaard-Larsen, S. 2009. Conservation farming strategies in East and Southern Africa: Yields and rainwater productivity from on-farm action research. Soil \& Tillage Research, 103: 23-32. 
Rusinamhodzi, L., Corbeels, M., van Wijk, M.T., Rufino, M. C., Nyamangara, J \& Giller, K. E. 2011. A meta-analysis of long-term effects of conservation agriculture on maize grain yield under rain-fed conditions. Agronomy for Sustainable Development, 31: 657-673.

Sornpoon, W \& Jayasuriya, H. P. W. 2013. Effect of different tillage and residue management practices on growth and yield of corn cultivation in Thailand.Agricultural Engineering International: CIGR Journal, 15(3): 86-94 (Open access, http://www.cigrjournal.org).

Taa, A., Tanner, D \& Bennie, A.T.P. 2004. Effects of stubble management, tillage and cropping sequence on wheat production in the south-easter highlands of Ethiopia. Soil and Tillage Research, 76: 69-82.

Urgessa Tilahun. 2014. Review of Production, Productivity and Marketability of Soya Bean in Ethiopia. eBook. http://www.grin.com/en/e-ook/292629/review-of-productionproductivity-and-marketability-of-soya-bean-in-ethiopia. Retrieved on 22/07/2016.

Willey, R. W. 1990. Resource use in intercropping systems. Agricultural Water Management, 17:215-231.

Willey, R. W., Natarajan, M., Reddy, M. S., Rao, M. R., Nambiar, P.T.C., Kannaiyan, J \& Bhatnagar, V.S. 1983. Intercropping studies with annual crops. In: J. Nugent and M. O'Connor (eds.), Better Crops for Food, Ciba Foundation Symposium, 97. London.

Willey, R. W. 1979. Intercropping-its importance and research needs. 1. Competition and yield advantages. Field crop abstracts, 32(1): 1-10.

Worku Burayu, Tewodros Mesfin, Hussein Mohammed, Tolesa Debelle, Tesfa Bogale \& Birtukan Mekonnen. 2001. A review of tillage management research on maize in Ethiopia. In: M. Nigussie, D. Tanner, and S. Twumasi-Afriyie (eds.), Enhancing the Contribution of Maize to Food Security in Ethiopia: Proceedings of the Second National Maize workshop of Ethiopia 12-16 November 2001. Addis Ababa, Ethiopia.

Wright, G. C., Smith, C. J \& Nelson, I. B. 1988.Growth and yield of soybean under wet soil culture and conventional furrow irrigation in South-Eastern Australia. Irrigation Science, 9: 127-192.

Yilmaz, F., Atak, M \& Erayman, M. 2008. Identification of Advantages of Maize-Legume Intercropping over Solitary Cropping through Competition Indices in the East Mediterranean Region. Turkis Journal of Agriculture and Forestry, 32: 111-119. 